\title{
Envenomation of a Puerto Rican Whiptail (Pholidoscelis exsul: Teiidae) by a Puerto Rican Racer (Borikenophis portoricensis: Dipsadidae) in Southern Puerto Rico
}

Alejandro J. Sánchez Muñoz

36 Calle Nevarez, Apt. 3-G, San Juan, Puerto Rico 00927 (ajtgsm@gmail.com)

Photographs by the author.

$\mathrm{X}^{\mathrm{s}}$ enodontine snakes are widely distributed members of West Indian island herpetofaunas. Among these, snakes in the genus Borikenophis (formerly Alsophis) occur on the Puerto Rican, Saint Croix, and Mona Banks (Mayer 2012). Dentition is opishtoglyphous (Weldon and Mackessy 2009) and small vertebrates, particularly frogs and lizards, comprise the primary prey (Rivero 1998).

The Puerto Rican Racer (Borikenophis portoricensis) is a medium-sized snake with larger individuals reaching a total length slightly over one meter (personal observation). It is an active diurnal forager that is mainly terrestrial but will readily climb trees. The species can be relatively common in certain areas of Puerto Rico and is found even in some urban environments near the capital city of San Juan (personal observation).

Although usually considered harmless to humans, these racers effectively use venom to subdue prey (Thomas and Prieto-Hernandez 1985; Rivero 1998). Under experimental conditions, the venom of $B$. portoricensis has been found to be hemolytic and highly toxic to both lizards and mice (Weldon and Mackessy 2009).
At 1100 h on 25 May 2018 in Camp Santiago, southeastern Puerto Rico, I encountered a small $(-30 \mathrm{~cm}$ total length) Puerto Rican Racer that had captured a juvenile Puerto Rican Whiptail (Pholidoscelis exsul). The snake had punctured the lizard's neck with its right fang before consuming its prey (Figs. 1-2). Instances of this snake using its rear fangs to inject venom into struggling prey have been documented (Henderson and Powell 2009). Although racers are not considered powerful constrictors despite having used constriction to kill laboratory mice in captivity (Rodríguez-Robles 1992), this snake had thrown several coils around the lizard to hold it prior to ingestion.

The lizard initially struggled actively against its attacker. However, within seconds of the first observation, it became motionless and began to expel blood from its mouth. I have seen similar symptoms in Green Iguanas (Iguana iguana; Fig. 3) and Puerto Rican Crested Anoles (Anolis cristatellus) after been bitten by racers. Presumably, the snake's venom quickly began destroying highly vascularized lung tissues, one of the first tissues affected by the venom of $B$. portoricensis
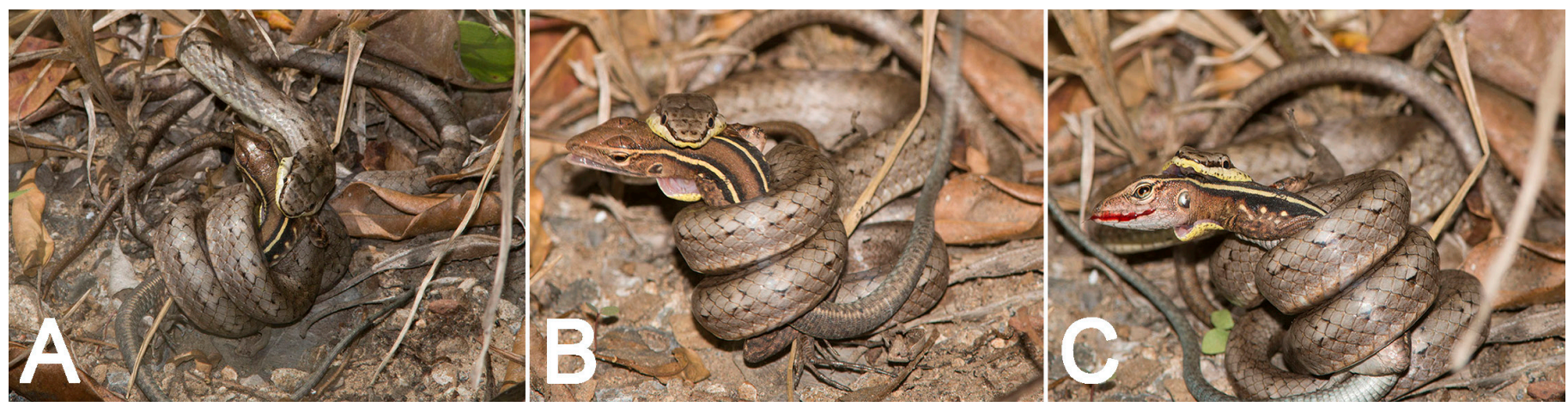

Fig. 1. A juvenile Puerto Rican Racer (Borikenophis portoricensis) envenomating a small Puerto Rican Whiptail (Pholidoscelis exul). Using several coils to hold its prey, the snake had punctured the lizard's neck with its right fang (A) before bringing both rear fangs into play (B). Within seconds, the lizard was motionless and expelled blood from its mouth (C). 

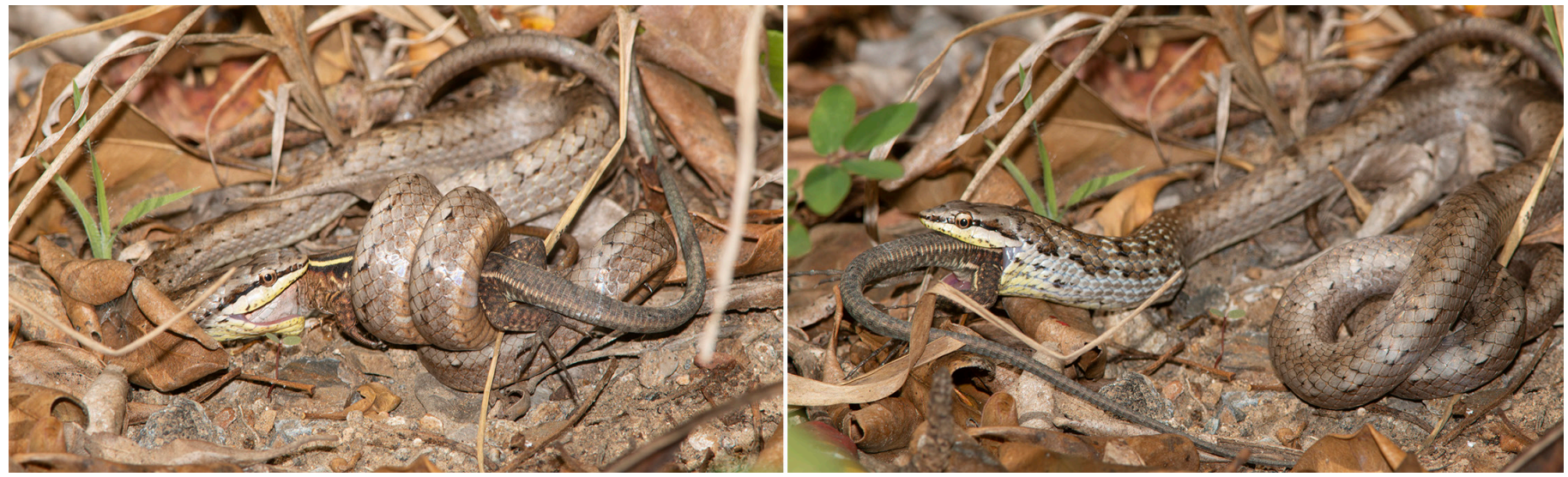

Fig. 2. A juvenile Puerto Rican Racer (Borikenophis portoricensis) ingesting a small Puerto Rican Whiptail (Pholidoscelis exul).

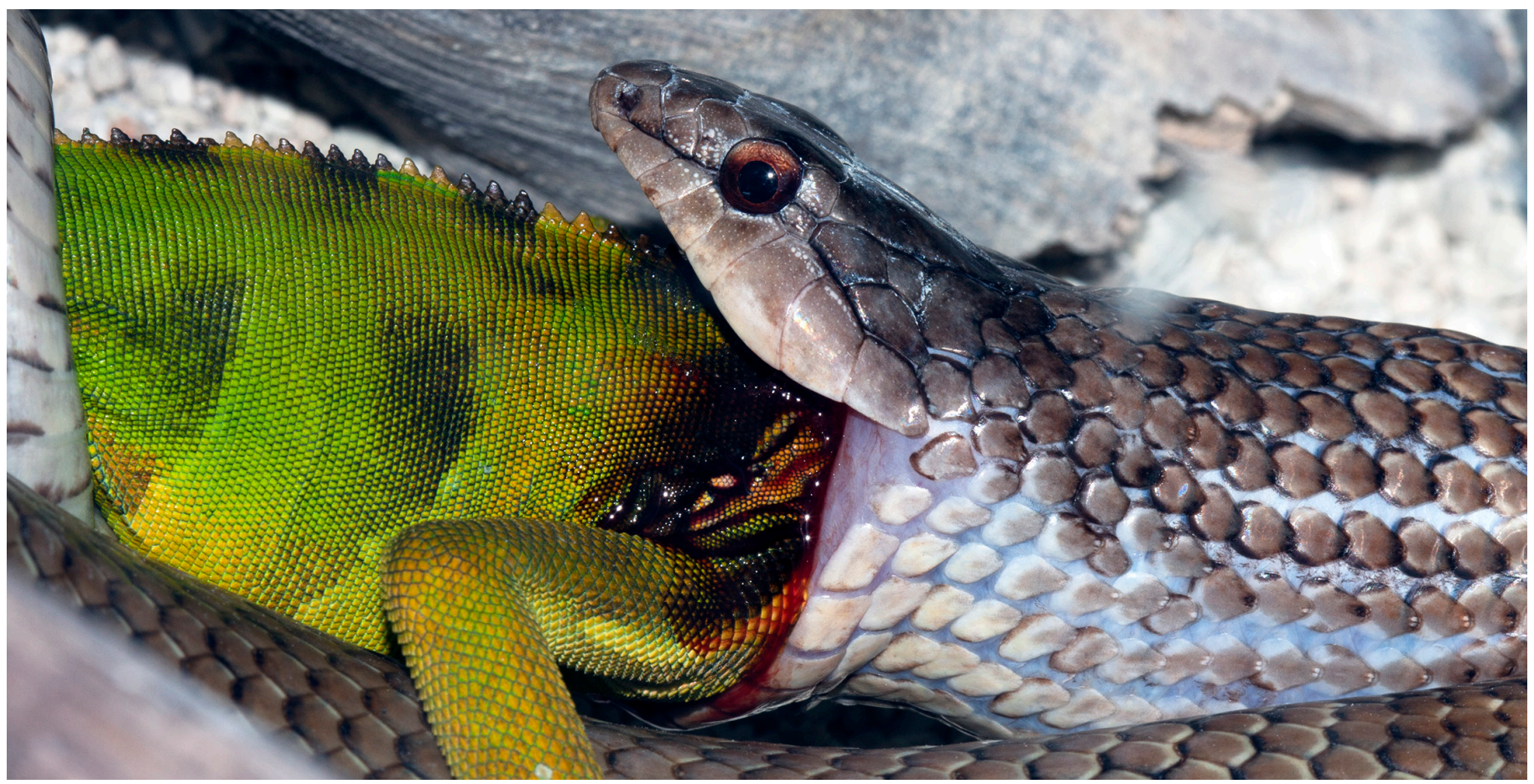

Fig. 3. An adult Puerto Rican Racer (Borikenophis portoricensis) swallowing a juvenile Common Iguana (Iguana iguana) in captivity. The blood evident on the lizard initially emerged as froth from its mouth before ingestion began.

(Rodríguez-Robles and Thomas 1992), in this case causing the prey to suffocate in its own blood before being consumed.

The snake dispatched its prey quickly and efficiently. Only about three minutes passed from my initial observation to the beginning of ingestion. The snake probably had captured the lizard shortly before I first noticed the pair. However, the fact that the lizard suddenly stopped struggling suggested that the venom acted quickly and was lethal. My conjecture is that if the snake's venom did not directly cause the lizard's paralysis, lack of oxygen due to the collapse of lung-tissue led to its death.

\section{Literature Cited}

Henderson, R.W. and R. Powell. 2009. Natural History of West Indian Reptiles and
Amphibians. University Press of Florida, Gainesville, Florida.

Mayer, G.C. 2012. Puerto Rico and the Virgin Islands, pp. 136-147. In: R. Powell and R.W. Henderson (eds.), Island lists of West Indian amphibians and reptiles. Bulletin of the Florida Museum of Natural History 51: 85-166.

Rivero, J.A. 1998. Los Anfibios y Reptiles de Puerto Rico. Secunda Edición Revisada. The Amphibians and Reptiles of Puerto Rico. Editorial de la Universidad de Puerto Rico, Rio Piedras, Puerto Rico.

Rodríguez-Robles, J.A. 1992. Notes on the feeding behavior of the Puerto Rican Racer, Alsophis portoricensis (Serpentes: Colubridae). Journal of Herpetology 26: 100-102.

Rodríguez-Robles, J.A and R. Thomas. 1992. Venom function in the Puerto Rican Racer, Alsophis portoricensis (Serpentes: Colubridae). Copeia 1992: 62-68.

Thomas, R. and J.A. Prieto-Hernandez. 1985. The use of venom by the Puerto Rican Snake, Alsophis portoricensis, pp. 13-22. In: Decimo Simposio de Recursos Naturales. Departamento de Recursos Naturales, University of Puerto Rico. Estado, Libre Asociado de Puerto Rico, San Juan, Puerto Rico.

Weldon, C.L. and S.P. Mackessy. 2009. Biological and proteomic analysis of venom from the Puerto Rican Racer (Alsophis portoricensis; Dipsadidae). Toxicon 55: 558-569. 